\title{
Up-regulation of fas reverses cisplatin resistance of human small cell lung cancer cells
}

\author{
Wei Wu+1, Hai-dong Wang ${ }^{+2}$, Wei Guo', Kang Yang², Yun-ping Zhao', Yao-guang Jiang ${ }^{* 1}$ and Ping He²
}

\begin{abstract}
Background/Aim: Fas/FasL system is a major regulator of apoptosis. The mechanisms by which Fas mediates cisplatin resistance remain unclear. The aim of this study is to explore the effect of Fas over-expression on cisplatin resistance of small cell lung cancer cells and its possible mechanisms.
\end{abstract}

Materials and methods: Fas was over-expressed in H446/CDDP cells by infection with the adenoviruses containing Fas. Sensitivity of Fas-overexpressed H446/CDDP cells to cisplatin was evaluated using MTT assay. Expressions of Fas, GST- $\pi$ and ERCC1 were detected by RT-PCR and Western blot analysis. Apoptosis rate was examined by FACS.

Results: Over-expression of Fas in H446/CDDP cells significantly decreased the expressions of GST- $\pi$ and ERCC1 at mRNA and protein levels, and increased the cell apoptosis. Furthermore, up-regulation of Fas significantly decreased the tolerance of H446/CDDP cells to cisplatin.

Conclusion: Over-expression of Fas reverses drug resistance of H446/CDDP cells, possibly due to the increased cell sensitivity to apoptosis and the decreased expressions of GST- $\pi$ and ERCC1.

\section{Background}

Small cell lung cancers (SCLC) are well known for their initial sensitivity to chemotherapeutic agents and thereafter frequent recurrence when tumors exhibit drug resistance. Cisplatin, formally known as cisdiamminedichloroplatinum (II) (CDDP), is a metal-base oncolitic agent that binds to the nucleophilic sites of DNA resulting in changes in DNA synthesis and cell death [1]. For this reason, cisplatin is commonly recommended for chemotherapeutical treatment of SCLC. However, many patients with SCLC exhibit drug resistance, which hampers the outcomes of cisplatin treatment.

It is well known that a number of cellular adaptations, including reduced drug uptake, drug inactivation by glutathione and other antioxidants, increased levels of DNA repair enzymes or DNA tolerance, and altered drug targets could cause resistance to CDDP, which may contribute to the poor survival rate of SCLC patients. Dysfunction of apoptotic signal transduction pathway of

\footnotetext{
* Correspondence: hpjwz@sina.com

1 Department of Thoracic Surgery, Institute of Surgery Research, Daping Hospital, Third Military Medical University, Chongqing 400042, PR China + Contributed equally

Full list of author information is available at the end of the article
}

malignant cells can also cause drug resistance. For example, down-regulation of pro-apoptotic genes such as Bax and Fas/FasL and up-regulation of anti-apoptotic genes such as Bcl-2 has been involved in drug resistance. Fas, a $45 \mathrm{kDa}$ type I transmembrane protein, is expressed on cell membranes of varieties of normal cells and malignant cells including lung cancer cells [2,3]. Its ligand, FasL, is expressed on the cell membrane of activated $\mathrm{T}$ lymphocytes and some malignant cells [4,5]. After trimerization of Fas on the cell membrane by extracellular FasL [6], Fasassociated death domain (FADD) and caspase 8 bind to the intracellular death domains of Fas and induce a death signal in the cells [7], leading to the activation of a cascade of caspases and eventually to cell death. Since FasL can induce apoptosis in Fas-expressing malignant cells, the Fas/FasL system plays an important role in $\mathrm{T}$ cellmediated cytotoxic reaction and malignant cell-mediated autocrine suicide or paracrine death against malignant cells. On the other hand, malignant cells can avoid being killed by down-regulating Fas expression. It has been demonstrated that cisplatin-resistant lung cancer cells express low level of Fas, and correspondingly, their apoptosis decreases significantly. Some reports have correlated multidrug resistance (MDR) with the decreased Fas expression and resistance to Fas-mediated apoptosis. Fas- 
resistant cells were resistant to chemotherapeutic drug treatment, which is presumably due to the disruption of pathways responsible for the induction of cell death by chemotherapeutic drugs [8].

Many agents can induce the expression of Fas, and thus promote the apoptosis of malignant cells. Cisplatin can enhance some solid tumors or leukaemic cell surface expression of Fas [9-11] via the activation of the acid sphingomyelinase (aSMase) and the generation of ceramide at the plasma membrane. Up-regulating the expression of melanoma differentiation-associated gene7/interleukin-24 (MDA-7/IL-24) can enhance the expression of Fas activated by cisplatin. Cisplatin can also enhance MDA-7/IL-24 toxicity via activation of the extrinsic pathway and de novo ceramide synthesis [12]. Bruno Segui et al proposed that it might be a way to treat cancer by enhancing the expression of Fas and promoting the apoptosis of tumor cell [13]. But in cisplatin-resistant human squamous cell carcinomas of the head and neck (SCCHN) cells, although the expression of Fas was enhanced by cisplatin or IFN- $\gamma$, the cisplatin sensitivity cannot be restored by agonistic Fas-antibodies [14]. However, the agonistic Fas-antibodies could restore the cisplatin sensitivity in other entities like bladder carcinomas [15]. Many factors may be involved, including that: 1 . High expression of drug-resistance genes such as glutathione S-transferase $\pi$ (GST- $\pi$ ) and excision repair crosscomplementing-1 (ERCC1) may be the major mechanism of drug resistance, and Fas-FasL system may be a minor one; 2. In SCCHN, the expression of Fas activated by cisplatin is p53-independent and may be ineffective activation, which was in contrast to many other solid tumors, where the antiproliferative effect of anticancer drugs is mediated at least in part by the Fas-FasL system via p53dependent mechanisms [16].

It is still obscure whether up-regulation of Fas expression can reverse cisplatin resistance, increase cisplatininduced apoptosis, and alter the expression of any drugresistant gene in human SCLC cells. To explore the possible role of Fas on cisplatin resistance in SCLC cells, we established a cisplatin-resistant SCLC cell line (H446/ CDDP), and constructed adenovirus vector containing Fas gene. By overexpressing Fas, we investigated the role of Fas in cisplatin sensitivity and apoptotic rate of SCLC cells. We also examined the levels of GST- $\pi$ and ERCC1, given their involvement in drug binding/inactivation and nucleotide excision repair (NER). Our results indicate that up-regulation of Fas could reverse cisplatin resistance of human SCLC cells by decreasing the expressions of GST- $\pi$ and ERCC1 and increasing Fas-mediated apoptosis.

\section{Methods}

\section{Cell lines and culture conditions}

Cisplatin was obtained from Ebewe Arzneimittel Ges.m.b.H. (Austria). Human SCLC cell line H446 was obtained from Academy of Military Medical Science (Beijing, China) and maintained in RPMI 1640 (Trace, Melbourne, Australia) supplemented with $10 \%$ fetal bovine serum (FBS), $100 \mathrm{U} / \mathrm{ml}$ penicillin, and $100 \mu \mathrm{g} / \mathrm{ml}$ streptomycin at $37^{\circ} \mathrm{C}$, in a humid atmosphere of $5 \% \mathrm{CO} 2 /$ 95\% air. Exposing them to gradually increasing concentrations of cisplatin (up to $30.8 \mu \mathrm{g} / \mathrm{ml}$ ) induced in vitro cisplatin-resistant cells. The obtained cell sublines H446/ CDDP were maintained in the absence of drug, and its drug resistance was stabilized by $30.8 \mu \mathrm{g} / \mathrm{ml}$ CDDP treatment for 4 days every 6 weeks. H446/CDDP is 39.0 times as resistant to cisplatin as its parental cell line. Cells from exponentially growing cultures were used for all experiments.

\section{Adenovirus vector construction and gene transduction}

Total RNA was extracted from H446 cells and first strand of cDNA was synthesized, the open reading frame (ORF) of human Fas gene was cloned using the primers with restriction endonuclease site as following: up primer $5^{\prime}$ GGGGTACC ATGCTGGGCATCTGGACCCTC 3'(Kpn I) and 5' GCTCTAGA TCACTCTAGACCAAGCTTTGG 3' (Xba I). PCR reaction was performed with 5 min of initial denaturation at $94^{\circ} \mathrm{C}, 30$ cycles of 30 $\mathrm{s}$ denaturation at $94^{\circ} \mathrm{C}, 30 \mathrm{~s}$ annealing at $61^{\circ} \mathrm{C}, 45 \mathrm{~s}$ extension at $72^{\circ} \mathrm{C}$, and finally $10 \mathrm{~min}$ extension at $72^{\circ} \mathrm{C}$. The PCR product of target fragment about 1013 bp was purified and ligased into T-vector, and the positive bacteria colonies were screened for sequencing by ampicillin resistance and blue-white screening with X-gal and IPTG. The Fas gene was subcloned to pAdTrack-CMV plasmid (a gift from Gang Huang, Third Military Medical University, Chongqing, China) and recombinants of pAdTrackCMV-Fas were generated by transformation the shuttle plasmid linearized with Pme I to BJ5183 cells with the adenoviruses backbone plasmid for homologous recombination. The recombinant adenoviruses were packaged and propagated in 293 cells. Viral titers were determined by standard plaque assay after the Fas adenoviruses concentrated by $\mathrm{CsCl}$ ultracentrifugation using a standard method [17].

H446/CDDP cells were transfected with 50 multiplicity of infection (MOI) of adenoviruses in serum free RPMI and maintained in complete medium at $37^{\circ} \mathrm{C}$ until posttransfection day 3 . The transfectants overexpressing Fas were obtained and designated as H446/CDDP/Fas. H446/ CDDP cells transfected with empty adenoviruses were indicated as H446/CDDP/Empty and used as negative control in all assays. 


\section{Conventional RT-PCR analysis}

On post-transfection day 3, total RNAs were isolated from H446/CDDP, H446/CDDP/empty, and H446/ CDDP/Fas cells using TRIzol reagent (TianGen, Beijing, China) and subsequently used for semiquantitative PCR. RT was performed with $1 \mu \mathrm{g}$ of total RNA from each sample using oligo(dT) 18 primers and 200 units of SuperScript II RT (Life Technologies Inc., Gaithersburg, Md., USA) for cDNA synthesis. cDNA amplification was conducted in $20 \mu \mathrm{l}$ solution containing $2 \mu \mathrm{l}$ of diluted cDNA, 10 pmol primer pairs for Fas, GST- $\pi$, ERCC1 and GAPDH, respectively, and $10 \mu \mathrm{l}$ of Taq PCR Master mix (TianGen, Beijing, China). The PCR consisted of initial denaturation at $94^{\circ} \mathrm{C}$ for $5 \mathrm{~min}$, followed by 30 reaction cycles $\left(30\right.$ seconds at $94^{\circ} \mathrm{C}, 30$ seconds at $61^{\circ} \mathrm{C}$, and 30 seconds at $72^{\circ} \mathrm{C}$ ) and a final cycle at $72^{\circ} \mathrm{C}$ for $10 \mathrm{~min}$. Primers used in PCR were listed in Table 1. GAPDH was used as internal control. All PCR products were electrophoretically separated on ethidium bromide-stained agarose gel and visualized with UV light.

\section{Real-time quantitative PCR (RT-qPCR)}

RT-qPCR was performed with ABI 7500 Thermal Cycler and SYBR Green qPCR kit (Toyobo, Japan). PCR reactions were prepared in low-profile microplates with each well containing $10 \mu \mathrm{l}$ of master mix, $2 \mu \mathrm{l}$ of diluted cDNA, 10 pmol each of primers listed in Table 1 for Fas, GST- $\pi$, ERCC1 and control GAPDH, respectively, in a $20 \mu \mathrm{l}$ reaction volume. The PCR consisted of initial denaturation at $94^{\circ} \mathrm{C}$ for $5 \mathrm{~min}$, followed by 30 reaction cycles ( 30 seconds at $94^{\circ} \mathrm{C}, 30$ seconds at $61^{\circ} \mathrm{C}$, and 30 seconds at $72^{\circ} \mathrm{C}$ ) and a final cycle at $72^{\circ} \mathrm{C}$ for $10 \mathrm{~min}$. Amplifications were performed in triplicate according to the cycling protocol provided by the manufacturer. Gene expression was expressed as $2^{-} \Delta \Delta(\mathrm{Ct})$ [18], where $\mathrm{Ct}$ is cycle threshold, $\Delta(\mathrm{Ct})=\mathrm{Ct}$ of tested gene - Ct of GAPDH; $\Delta \Delta(\mathrm{Ct})=\Delta(\mathrm{Ct})$ of sample $1-\Delta(\mathrm{Ct})$ of sample 2 .

Table 1: PCR primer sequences and product sizes.

\section{Western blot analysis}

The mouse anti-human Fas (cat. sc-74540), GST- $\pi$ (cat. sc-58368) and rabbit anti-human ERCC1(cat. sc-10785) antibodies and horseradish peroxidase(HRP)-conjugated goat anti-rabbit and goat anti-mouse immunoglobulin $\mathrm{G}$ (IgG) were obtained from Santa Cruz Biotechnology (Santa Cruz, Calif., USA). $5 \times 10^{6}$ H446/CDDP Cells were seeded into $100 \mathrm{~mm}$ plates, incubated for $24 \mathrm{~h}$ at $37^{\circ} \mathrm{C}$, and then transfected with $50 \mathrm{MOI}$ of adenoviruses. On post-transfection day 3, H446/CDDP, H446/CDDP/Fas, and $\mathrm{H} 446 / \mathrm{CDDP} / \mathrm{empty}$ cells were washed three times with cold phosphate buffered saline (PBS) and then lysed in RIPC buffer (0.5 M NaCl, 0.5\% NP-40, $20 \mathrm{mM}$ Tris$\mathrm{HCl} \mathrm{pH} \mathrm{8,} 1$ mM PMSF). The protein levels were determined using an ECL kit ((Amersham Pharmacia, Uppsala, Sweden). Total cellular proteins were diluted 2-fold into SDS-PAGE loading buffer (NEB). The samples were heated to $95^{\circ} \mathrm{C}$ for $5 \mathrm{~min}$ before an aliquot of $20 \mu \mathrm{l}$ of each diluted assay sample, containing approximately $50 \mathrm{ug}$ of total protein, was loaded onto a 6-12\% Tris-glycine polyacrylamide gel (Invitrogen). Proteins were resolved by SDS-PAGE and then transferred to a $0.45 \mu \mathrm{m}$ nitrocellulose membrane (Whatman). The membrane was blocked with $5 \%$ nonfat dry milk in Tris-buffered saline $(50 \mathrm{mM}$ Tris- $\mathrm{HCl}, \mathrm{pH} 7.5,150 \mathrm{mM} \mathrm{NaCl}$ ) supplemented with $0.2 \%$ Tween 20 and $0.05 \%$ Triton X-100 (TBSTT). The membrane was probed with the primary antibody at 1:700 dilution in TBSTT supplemented with $2 \%$ nonfat dry milk. After an overnight incubation at $4^{\circ} \mathrm{C}$, the membrane was washed and incubated at room temperature for $2 \mathrm{~h}$ with a goat anti-rabbit or mouse HRP-linked IgG antibody (1:700 dilution in TBSTT with $2 \%$ dry milk). Binding of the antibody was detected by chemiluminescence with the Phototope-HRP Western Blot Detection System (CST).

\section{In vitro drug sensitivity assay}

Drug sensitivity was evaluated using 3-(4,5-dimethylthiazol-2-yl)-2,5-diphenyl-tetrazolium bromide (MTT)

\begin{tabular}{|c|c|c|c|}
\hline Primersa & Oligonucleotide Sequences & Product Size (bp) & PCR Cycles \\
\hline \multirow[t]{2}{*}{ Fas } & F: 5'GTCCAAAAGTGTTAATGCCCAAGT 3' & 232 & 30 \\
\hline & R: 5'ATGGGCTITGTCTGTGTACTCCT 3' & & \\
\hline \multirow[t]{2}{*}{ GST- $\pi$} & F: 5' CCGCCCTACACCGTGGTCTAT 3' & 260 & 30 \\
\hline & R: 5' GCTGCCTCCTGCTGGTCCTT 3' & & \\
\hline \multirow[t]{2}{*}{ ERCC1-2 } & F: 5' ACGCCGAATATGCCATCTCAC 3' & 292 & 30 \\
\hline & R: 5' AGCCGCCCATGGATGTAGTCT 3' & & \\
\hline \multirow[t]{2}{*}{ GAPDH } & F: 5' ACCCATCACCATCTTCCAGGAG 3' & 159 & 30 \\
\hline & R: 5' GAAGGGGCGGAGATGATGAC 3' & & \\
\hline
\end{tabular}

a All primers were designed using genetool software. 
assay. Briefly, on post-transfection day 3, the transfected cells and control cells were seeded into 96-well plates with $10^{3}$ cells per well and incubated overnight. Cells were then incubated with CDDP in different concentrations $(5,10,15,20,25,30,35,40,45$, and $50 \mu \mathrm{g} / \mathrm{ml})$. After $72 \mathrm{~h}$ of incubation, $20 \mu \mathrm{l}$ of $5 \mathrm{mg} / \mathrm{ml}$ MTT (Sigma Chemical Co., St Louis, MO) in PBS was added to each well, followed by incubation for $4 \mathrm{~h}$ at $37^{\circ} \mathrm{C}$. The formazan crystals were dissolved in $50 \mu \mathrm{l}$ of dimethyl sulfoxide (DMSO). The optimal density was determined with microculture plate reader (Becton Dickinson Labware, Lincoln Park, NJ) at $570 \mathrm{~nm}$. Absorbance values were normalized to the values obtained for control cell to determine the proportion of survival [19]. The IC50 values were the drug concentrations causing a 50\% reduction in the optical density. The experiments were performed in triplicate, and expressed as the mean values of three experiments.

The relative resistance was calculated by the following formula:

Relative resistance $=\left(\mathrm{IC}_{50}\right.$ of $\mathrm{H} 446 / \mathrm{CDDP} /$ Fas cells $) /\left(\mathrm{IC}_{50}\right.$ of H446 $/ \mathrm{CDDP} /$ Empty cells $)$.

\section{Apoptosis analysis}

On post-transfection day 3, cells were resuspended in 100 $\mu \mathrm{l}$ binding buffer at a concentration of $1 \times 10^{6} / \mathrm{ml}$ after washing twice with cold PBS and mixed with $5 \mu \mathrm{l}$ Annexin V-FITC (PharMingen) and $10 \mu \mathrm{l}$ of $20 \mu \mathrm{g} / \mathrm{ml}$ propidium iodide (Sigma) at room temperature for 15 min. Samples were diluted with $400 \mu$ l binding buffer and analyzed by fluorescence activated cell sorting (FACS) using the protocol provided by the manufacturer (ClonTech, Palo Alto, Calif., USA). The apoptotic rate was calculated as the mean fluorescence intensity.

\section{Statistical analysis}

The data are expressed as the mean \pm SEM. Each experiment was repeated at least three times. Bands from Western blots were quantified by Quantity One software (BioRad). The differences among means were examined with ANOVA followed by post-hoc test using SPSS 11.0 software (Chicago, Ill., USA). A p value less than 0.05 was considered as statistical significance.

\section{Results}

\section{RT-PCR and Western blots}

Both mRNA and protein levels of Fas were significantly lower in H446/CDDP and H446/CDDP/Empty cells compared with those in H446/CDDP/Fas cells ( $\mathrm{p}<0.01$ ), indicating that Fas was successfully transduced into and expressed in H446/CDDP cells. Over-expression of Fas effectively down-regulated ERCC1 and GST- $\pi$ in both
mRNA and protein levels $(\mathrm{p}<0.01)$ compared with the control cells (Figs. 1 and 2).

\section{Effect of Fas on cisplatin resistance}

To explore the roles of Fas in cisplatin resistance of SCLC, MTT assays were performed. $72 \mathrm{~h}$ after exposure to CDDP, the $50 \%$ inhibitory concentration $\left(\mathrm{IC}_{50}\right)$ of CDDP in $\mathrm{H} 446 / \mathrm{CDDP} / \mathrm{Fas}$ was $7.6 \pm 0.46 \mu \mathrm{g} / \mathrm{ml}$, significantly lower than $30.8 \pm 0.92 \mu \mathrm{g} / \mathrm{ml}$ and $29.7 \pm 0.26 \mu \mathrm{g} / \mathrm{ml}$ in H446/CDDP and H446/CDDP/Empty, respectively ( $\mathrm{p}<$ 0.01 ). In other words, H446/CDDP/Fas cells showed a 3.9-fold decrease in resistance to CDDP compared with H446/CDDP/Empty cells, suggesting that up-regulation of Fas could inhibit the cisplatin-resistant phenotype of SCLC.

\section{Effect of Fas on cell apoptosis}

The apoptosis rates in H446/CDDP, H446/CDDP/Empty and $\mathrm{H} 446 / \mathrm{CDDP} / \mathrm{Fas}$ cells were $6.02 \pm 0.70 \%, 7.19 \pm$ $0.89 \%$ and $13.17 \pm 0.40 \%$, respectively. Compared to H446/CDDP and H446/CDDP/Empty cells, H446/

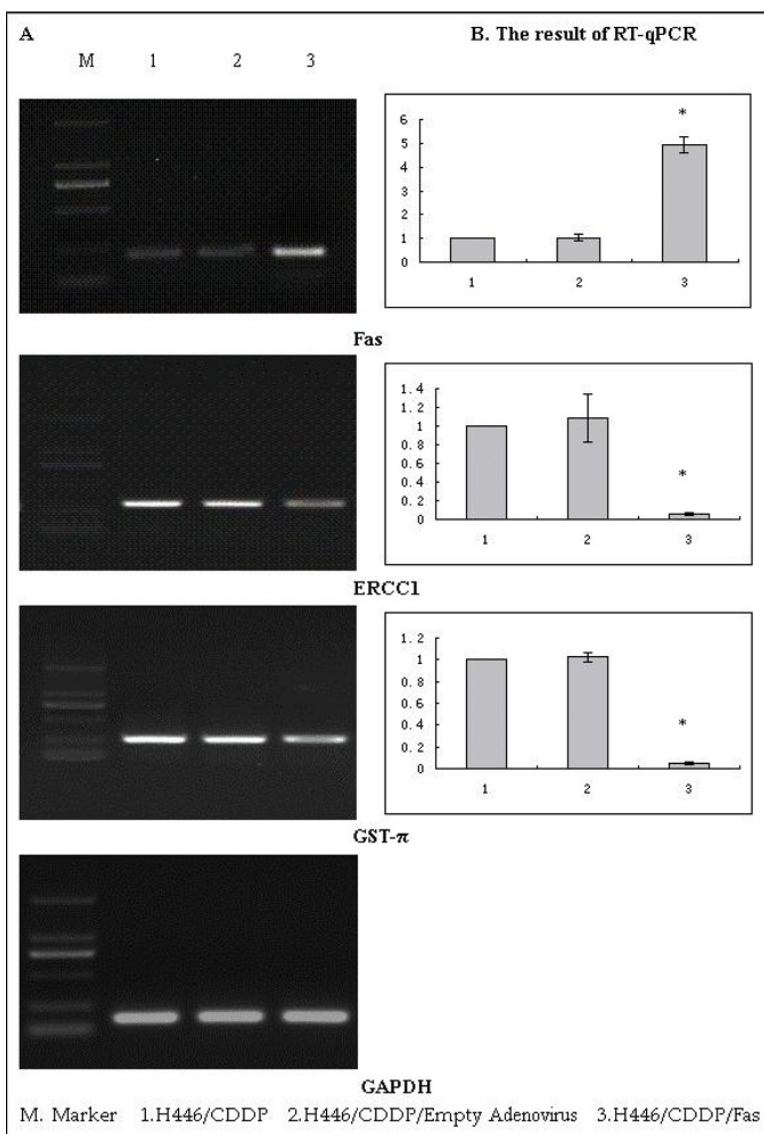

Figure 1 The expression of Fas, ERCC1, GST- $\pi$ and GAPDH detected by RT-qPCR. GAPDH was used as an internal control. Upregulation of Fas led to a significant decrease in ERCC1 and GST-п. ${ }^{*} p<0.01$ vs H446/CDDP/Empty and H446/CDDP cells. 


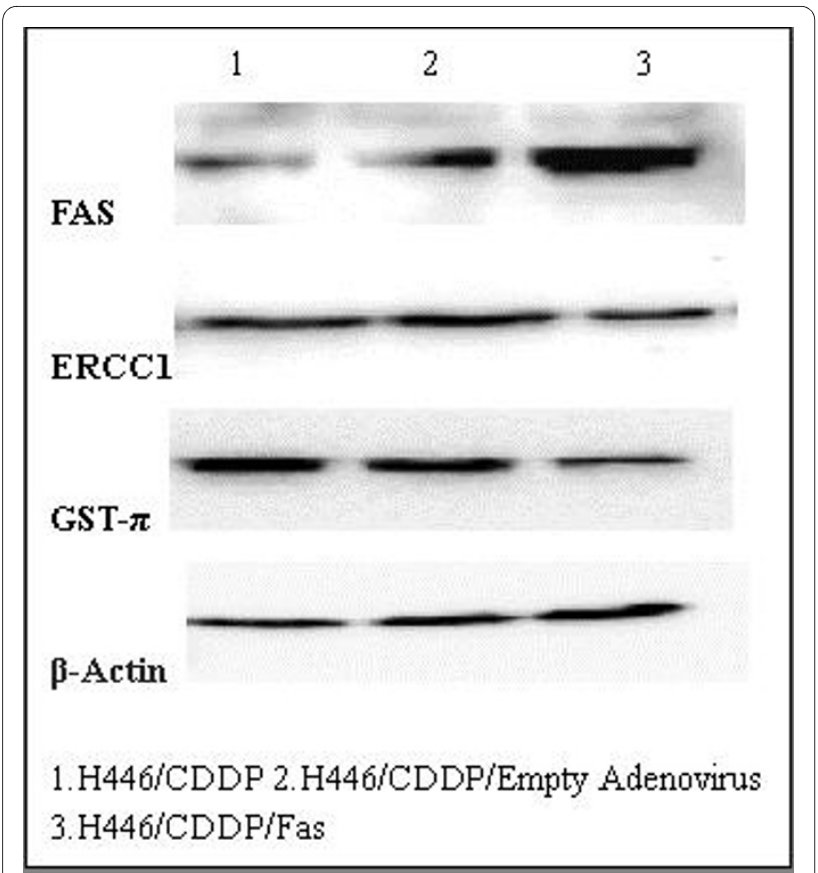

Figure 2 The expression of Fas, ERCC1, and GST- $\pi$ detected by Western blots. $\beta$-actin was used as an internal control. Upregulation of Fas caused the downregulation of ERCC1, and GST- $\pi$.

$\mathrm{CDDP} /$ Fas cells showed a significantly lower apoptotic rate $(\mathrm{p}<0.01$, Fig. 3$)$, suggesting that the up-regulation of Fas promoted the apoptosis in H446/CDDP cells.

\section{Discussions}

As one of the most widely used platinum-containing anticancer drugs, CDDP is believed to induce tumor cell death as a result of the formation of CDDP-DNA adducts, which inhibits DNA replication and transcription [20]. The presence of intrinsic or acquired resistance to CDDP in cancer cells limits curative effects of chemotherapy. Therefore, understanding the precise mechanisms of CDDP resistance and reversing it would provide new strategies for cancer therapy.

The balance of Fas/FasL interaction between the host immune system and malignant cells may be crucially involved in determining sensitivity or resistance towards chemotherapy. In several malignant cell lines, including SCLC cell lines, commonly used chemotherapeutic drugs have been shown to induce Fas expression [21]. Cisplatin can promote apoptosis of malignant cells by inducing Fas expression, which is one of the mechanisms of cisplatin killing the malignant cells. For instance, cisplatin could up-regulate expressions of Fas and FasL, activate caspase 8 pathways and induce apoptosis in uterine cervix cancer cells [22]. Matsuzaki I et al [23] found that cisplatin could induce Fas expression in esophageal cancer cell lines and enhance cytotoxicity in combination with LAK cells. Lan
F. Qin et al [24] found that cisplatin could induce expression of Fas in hepatoma cells, which was correlated with the appearance of cisplatin-induced apoptosis. But the cisplatin-resistant malignant cells usually express low level of Fas, and correspondingly, the apoptosis of malignant cells decreases significantly. Fas-resistant cells are resistant to chemotherapeutic drug treatment, which is presumably due to the disruption of the pathway responsible for cell death induced by chemotherapeutic drugs [25]. In our study, the enhanced mRNA and protein expressions of Fas in cisplatin-resistant SCLC cells correspondingly increases SCLC cell apoptosis.

The mechanisms of resistance to CDDP are multifactorial, and many genes or gene products have been reportedly responsible for CDDP resistance [26]. Cisplatin is most efficiently removed from transcribed areas within DNA, and gene-specific repair efficiency of cross-links correlates with cisplatin resistance [27]. Platinum damage is repaired primarily by the nucleotide excision repair (NER) system (particularly ERCC1 and ERCC1/XPF) and the related genes XPA and BRCA1 [28,29]. Previous studies have found that increased expression of ERCC1, an important NER protein, is correlated with CDDP resistance. For instance, expression of ERCC 1 has been shown to increase the resistance to platinum treatment in patients with ovarian cancer [30]. Similarly, non-small cell lung carcinoma (NSCLC) displayed a correlation between CDDP resistance and ERCC1 levels [31-33]. Testicular cancer, generally very responsive to CDDP, has low level of ERCC1, providing further correlative evidence for the importance of ERCC1 in CDDP resistance [34]. Given its involvement in the NER DNA repair pathway, we paid special attention to ERCC1. A previous study has proved that the suppression of ERCC1 expression in human cancer cells leads to an increased sensitivity to CDDP, and ERCC1 has been presumed to be an attractive target to confer increased cellular sensitivity to CDDP-based chemotherapy [35]. The results of this study suggest that the expression of ERCC1 is significantly down-regulated with the transfection of Fas in H446/ CDDP cells, which may contribute to the decreased resistance to CDDP.

Increased glutathione (GSH) may cause resistance by binding/inactivating cisplatin, enhancing DNA repair, or reducing cisplatin-induced oxidative stress [36]. Glutathione-S-transferase (GST), particularly GST- $\pi[37,38]$, may augment drug resistance by catalyzing GSH-drug binding. Clinically, GST- $\pi$ gene amplification [39], immunostaining [40], and plasma levels [41] have been correlated with cisplatin resistance, suggesting that platinum detoxification by GSH and GST may be clinically important. The results of this study suggest that the expression of GST- $\pi$ is significantly down-regulated with the transfec- 


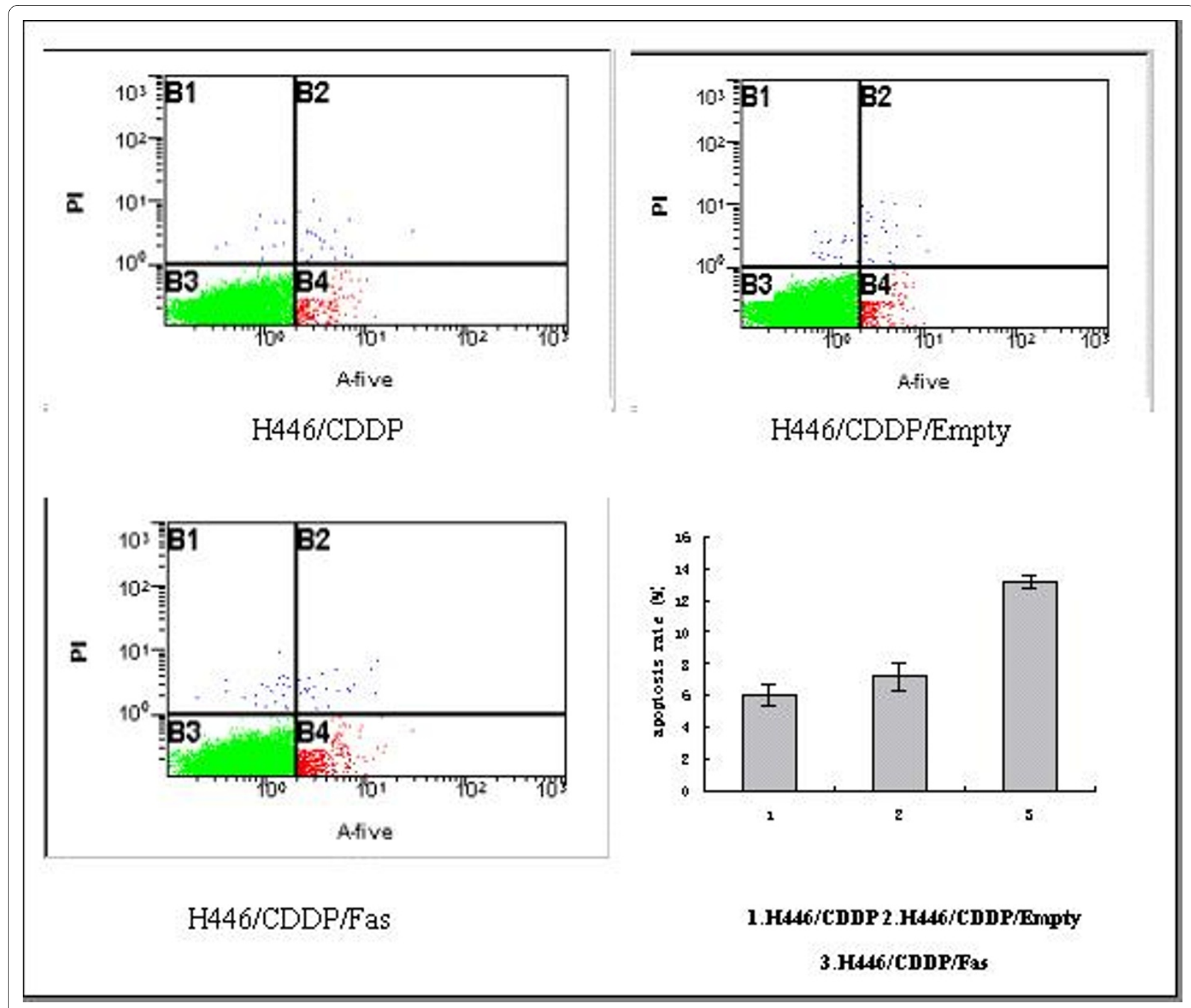

Figure 3 The apoptotic rate of H446/CDDP, H446/CDDP/Empty, and H446/CDDP/Fas cells. Compared to H446/CDDP and H446/CDDP/Empty cells, H446/CDDP/Fas cells had a significantly increased apoptotic rate $(p<0.01)$.

tion of Fas in H446/CDDP cells, which may contribute to the decreased resistance to CDDP.

\section{Conclusion}

Our results show that Fas gene transduction can reverse the multidrug resistance (MDR) of human drug resistant SCLC cell H446/CDDP, for which the enhanced cell sensitivity to apoptosis and decreased expression of GST- $\pi$ and ERCC1 may be responsible. Although the biological function of Fas in SCLC needs to be further investigated, the present results of our study provide a framework for the illumination of the resistance to CDDP mediated by Fas, and will aid in the effective use of CDDP in SCLC treatment.

Competing interests

The authors declare that they have no competing interests.

\section{Authors' contributions}

WW: Participated in research design, the writing of the paper, the performance of the research and data analysis. HDW: Participated in research design, the performance of the research and data analysis. WG: Participated in research design. KY: Participated in research design, the performance of the research and data analysis. YPZ: Participated in research design. YGJ: Participated in research design, the writing of the paper, the performance of the research and data analysis. PH: Participated in the writing of the paper and data analysis. There is no conflict of interest for each author. All authors read and approved the final manuscript.

\section{Acknowledgements}

This work was supported by grants from the National Natural Science Foundation of China (No. 30772145) and the Natural Science Foundation Project of CQ_CSTC (No. CSTC. 2006BB5081).

\section{Author Details}

'Department of Thoracic Surgery, Institute of Surgery Research, Daping Hospital, Third Military Medical University, Chongqing 400042, PR China and 2Department of Thoracic Surgery, Southwest Hospital, Third Military Medical University, Chongqing 400038, PR China 
Received: 27 February 2010 Accepted: 14 May 2010

Published: 14 May 2010

\section{References}

1. Eastman A: Activation of programmed cell death by anticancer agents: cisplatin as a model system. Cancer Cell 1990, 2:275-280.

2. Watanabe-Fukunaga R, Brannan Cl, Itoh N, Yonehara S, Copeland NG, Jenkins NA, Nagata S: The CDNA structure, expression, and chromosomal assignment of the mouse Fas antigen. J Immunol 1992, 148:1274-9.

3. Nagata S: Fas and Fas ligand: a death factor and its receptor. Adv Immunol 1994, 57:129-44.

4. Ungefroren $H$, Voss $M$, Jansen M, Roeder C, Henne-Bruns D, Kremer B, Kalthoff $\mathrm{H}$ : Human pancreatic adenocarcinomas express Fas and Fas ligand yet are resistant to Fas mediated apoptosis. Cancer Res 1998, 58:1741-9.

5. Von BernstorffW, Spanjaard RA, Chan AK, Lockhart DC, Sadanaga N, Wood I, Peiper M, Goedegebuure PS, Eberlein TJ: Pancreatic cancer cells can evade immune surveillance via nonfunctional Fas (APO-1/CD95) receptors and aberrant expression of functional Fas ligand. Surgery 1999, 125:73-84

6. Huang B, Eberstadt M, Olejniczak ET, Meadows RP, Fesik SW: NMR structure and mutagenesis of the Fas (APO-1/CD95) death domain. Nature 1996, 384:638-641.

7. Debatin KM, Beltinger C, Bohler T, Fellenberg J, Friesen C, Fulda S, Herr I, Los M, Scheuerpflug C, Sieverts H, Stahnke K: Regulation of apoptosis through CD95 (APO-I/Fas) receptor-ligand interaction. Biochem Soc Trans 1997, 25:405-410.

8. Los M, Herr I, Friesen C, Fulda S, Schulze-Osthoff K, Debatin K-M: Crossresistance of CD95- and drug-induced apoptosis as a consequence of deficient activation of caspases (ICE/ced-3 proteases). Blood 1997, 90:3118-3129.

9. Friesen C, Herr I, Krammer PH, Debatin KM: Involvement of the CD95 (APO-1/FAS) receptor/ligand system in drug-induced apoptosis in leukemia cells. Nat Med 1996, 2:574-7.

10. Micheau O, Solary E, Hammann A, Martin F, Dimanche-Boitrel MT: Sensitization of cancer cells treated with cytotoxic drugs to Fasmediated cytotoxicity. J Natl Cancer Inst 1997, 89:783-9.

11. Muller M, Wilder S, Bannasch D, Israeli D, Lehlbach K, Li-Weber M, Friedman SL, Galle PR, Stremmel W, Oren M, Krammer PH: p53 activates the CD95 (APO-1/Fas) gene in response to DNA damage by anticancer drugs. J Exp Med 1998, 188:2033-45.

12. Yacoub Adly, Liu Renyan, Park Margaret A, Hamed Hossein A, Dash Rupesh, Schramm Danielle N, Sarkar Devanand, Dimitriev Igor P, Bell Jessica K, Grant Steven, Farrell Nicholas P, Curiel David T, Fisher Paul B, Dent Paul: Cisplatin Enhances Protein Kinase R-Like Endoplasmic Reticulum Kinase- and CD95-Dependent Melanoma DifferentiationAssociated Gene-7/Interleukin-24-Induced Killing in Ovarian Carcinoma Cells. Mol Pharmacol 2010, 77:298-310

13. Segui Bruno, Legembre Patrick: Redistribution of CD95 into the Lipid Rafts to Treat Cancer Cells? Recent Patents on Anti-Cancer Drug Discovery 2010, 5:22-28

14. Sproll Karl Christoph, Ballo Hilmar, Hoffmann Thomas K, Scheckenbach Kathrin, Koldovsky Ursula, Balz Vera, Hafner Dieter, Ramp Uwe, Bier Henning: Is there a role for the Fas-/Fas-Ligand pathway in chemoresistance of human squamous cell carcinomas of the head and neck (SCCHN)? Oral Oncology 2009, 45:69-84.

15. Mizutani Y, Wu XX, Yoshida O, Shirasaka T, Bonavida B: Chemoimmunosensitization of the T24 human bladder cancer line to Fas-mediated cytotoxicity and apoptosis by cisplatin and 5fluorouracil. Oncol Rep 1999, 6:979-82

16. Muller M, Strand S, Hug H, Heinemann EM, Walczak H, Hofmann WJ, Stremmel W, Krammer PH, Galle PR: Drug-induced apoptosis in hepatoma cells is mediated by the CD95 (APO-1/Fas) receptor/ligand system and involves activation of wild-type p53. J Clin Invest 1997, 99(3):403-13.

17. Hitt M, Bett AJ, Prevec L, Graham FL: Construction and propagation of human adenovirus vectors. In Cell Biology: Laboratory Handbook Academic Press, New York; 1994:479-490.
18. Pfaffl MW, Horgan GW, Dempfle L: Relative expression software tool (REST) for group-wise comparison and statistical analysis of relative expression results in real-time PCR. Nucleic Acids Res 2002, 30:e36.

19. Simon SM, Schindler M: Cell biological mechanism of multidrug resistance in tumors. Proc Natl Acad Sci USA 1994, 91:3497-3504.

20. Szymkowski DE, Yarema K, Essigmann JM, Lippard SJ, Wood RD: An intrastrand $\mathrm{d}(\mathrm{GpG})$ platinum crosslink in duplex M13 DNA is refractory to repair by human cell extracts. Proc Natl Acad Sci USA 1992, 89:10772-10776

21. Volm M, Rittgen W: Cellular predictive factors for the drug response of lung cancer. Anticancer Res 2000, 20(5B):3449-58.

22. Toyozumi Y, Arima N, Izumaru S, Kato S, Morimatsu M, Nakashima T: Loss of caspase-8 activation pathway is a possible mechanism for CDDP resistance in human laryngeal squamous cell carcinoma, HEp-2 cells[J]. Int J Oncol 2004, 25(3):721-728.

23. Matsuzaki I, Suzuki H, Kitamura M, Minamiya Y, Kawai H, Ogawa J: Cisplatin induces fas expression in esophageal cancer cell lines and enhanced cytotoxicity in combination with LAK cells [J]. Oncology 2000, 59(4):336-343

24. Qin LF, Ng IO: Induction of apoptosis by cisplatin and its effect on cell cycle-related proteins and cell cycle changes in hepatoma cells. Cancer Letters 2002, 175:27-38.

25. Los M, Herr I, Friesen C, Fulda S, Schulze-Osthoff K, Debatin K-M: Crossresistance of CD95- and drug-induced apoptosis as a consequence of deficient activation of caspases (ICE/ced-3 proteases). Blood 1997 90:3118-3129.

26. Gosland M, Lum B, Schimmelpfennig J, Baker J, Doukas M: Insights into mechanisms of cisplatin resistance and potential for its clinical reversal. Pharmacotherapy 1996, 16:16-39.

27. Zhen W, Link CJ Jr, O'Connor PM, Reed E, Parker R, Howell SB, Bohr VA: Increased gene-specific repair of cisplatin interstrand cross-links in cisplatin-resistant human ovarian cancer cell lines. Mol Cell Biol 1992, 12:3689-98.

28. Reed E: Platinum-DNA adduct, nucleotide excision repair and platinum based anti-cancer chemotherapy. Cancer Treat Rev 1998, 24:331-44.

29. Dabholkar M, Vionnet J, Bostick-Bruton F, Yu JJ, Reed E: Messenger RNA levels of XPAC and ERCC1 in ovarian cancer tissue correlate with response to platinum-based chemotherapy. J Clin Invest 1994, 94:703-8.

30. Li Q, Yu JJ, Mu C, Yunmbam MK, Slavsky D, Cross CL, Bostick-Bruton F, Reed E: Association between the level of ERCC-1 expression and the repair of cisplatin-induced DNA damage in human ovarian cancer cells. Anticancer Res 2000, 20:645-652.

31. Rosell R, Cobo M, Isla D, Sanchez JM, Taron M, Altavilla G, Santarpia M, Moran T, Catot S, Etxaniz O: Applications of genomics in NSCLC. Lung Cancer 2005, 50(Suppl 2):S33-40

32. Huang PY, Liang XM, Lin SX, Luo RZ, Hou JH, Zhang L: Correlation analysis among expression of ERCC-1, metallothionein, $\mathrm{p} 53$ and platinum resistance and prognosis in advanced non-small cell lung cancer. $A i$ Zheng 2004, 23:845-50.

33. Rosell R, Taron M, Barnadas A, Scagliotti G, Sarries C, Roig B: Nucleotide excision repair pathways involved in Cisplatin resistance in non-smallcell lung cancer. Cancer Control 2003, 10:297-305.

34. Welsh C, Day R, McGurk C, Masters JRW, Wood RD, Köberle B: Reduced levels of XPA, ERCC1 and XPF DNA repair proteins in testis tumor cell lines. Int J Cancer 2004, 110:352-361.

35. Chang IY, Kim MH, Kim HB, Lee DY, Kim SH, Kim HY, You HJ: Small interfering RNAinduced suppression of ERCC1 enhances sensitivity of human cancer cells to cisplatin. Biochem Biophys Res Commun 2005, 327:225-233.

36. Siddik ZH: Cisplatin: mode of cytotoxic action and molecular basis of resistance. Oncogene 2003, 22:7265-79.

37. Surowiak P, Materna V, Kaplenko I, Marek S, Dietel M, Lage H, Zabel M: Augmented expression of metallothionein and glutathione Stransferase pi as unfavourable prognostic factors in cisplatin-treated ovarian cancer patients. Virchows Arch 2005, 447:626-33.

38. Kimura S, Imagawa Y, Satake K, Tsukuda M: The relationship of the human glutathione S-transferase PI polymorphism and chemotherapeutic sensitivity in head and neck squamous carcinoma. Int J Mol Med 2004, 14:185-9.

39. Cullen KJ, Newkirk KA, Schumaker LM, Aldosari N, Rone JD, Haddad BR: Glutathione S-transferase pi amplification is associated with cisplatin 
resistance in head and neck squamous cell carcinoma cell lines and primary tumors. Cancer Res 2003, 63:8097-102.

40. Kase H, Kodama S, Nagai E, Tanaka K: Glutathione S-transferase pi immunostaining of cisplatin-resistant ovarian cancer cells in ascites. Acta Cytol 1998, 42:1397-402.

41. Cabelguenne A, Loriot MA, Stucker I, Blons H, Koum-Besson E, Brasnu D, Beaune P, Laccourreye O, Laurent-Puig P, Waziers ID:

Glutathioneassociated enzymes in head and neck squamous cell carcinoma and response to cisplatin-based neoadjuvant chemotherapy. Int J Cancer 2001, 93:725-30.

doi: 10.1186/1756-9966-29-49

Cite this article as: Wu et al., Up-regulation of fas reverses cisplatin resistance of human small cell lung cancer cells Journal of Experimental \& Clinical Cancer Research 2010, 29:49

Submit your next manuscript to BioMed Central and take full advantage of:

- Convenient online submission

- Thorough peer review

- No space constraints or color figure charges

- Immediate publication on acceptance

- Inclusion in PubMed, CAS, Scopus and Google Scholar

- Research which is freely available for redistribution

Submit your manuscript at www.biomedcentral.com/submit
() BioMed Central 